Maciej Olejnik

ORCID: 0000-0002-8697-3158

Centrum Studiów Niemieckich i Europejskich im. Willy'ego Brandta Uniwersytetu Wrocławskiego

\title{
Ewolucja reżimu politycznego w Polsce w okresie funkcjonowania rządu Beaty Szydło
}

DOI: $10.19195 / 1643-0328.26 .2$

Słowa kluczowe: reżim polityczny, demokracja liberalna, demokracja nieliberalna, rządy prawa

\section{Wprowadzenie}

Przedmiotem opracowania jest analiza procesu ewolucji demokratycznego reżimu politycznego w Polsce w okresie funkcjonowania rządu Beaty Szydło (16 listopada 201511 grudnia 2017). Na potrzeby artykułu za państwo demokratyczne uznano takie, w którym odbywają się wolne, rywalizacyjne wybory oraz realnie funkcjonuje wolność słowa i swoboda zrzeszania się, a obywatele mają dostęp do alternatywnych źródeł informacji (Robert Dahl nazywał taki system poliarchią pełną ${ }^{1}$ ). Zgodnie $\mathrm{z}$ tą definicją Polska ponownie stała się państwem demokratycznym w październiku 1991 roku —zostały wówczas przeprowadzone wybory do Sejmu i Senatu, które „zamknęły proces formowania się demokratycznych władz III Rzeczypospolitej"2.

Pojęcie reżimu politycznego było rozumiane zgodnie z interpretacją Andrzeja Antoszewskiego, który uważał, że obejmuje ono „wartości i zasady ustrojowe (wolność, równość, podział władzy)”" , a także „strukturę autorytetów, formalne i nieformalne »reguły gry politycznej« oraz wynikające z nich zachowania i relacje między podmiotami polityki”" . Zdaniem Andrzeja Antoszewskiego reżimy polityczne można podzielić na demokratyczne i niedemokratyczne ${ }^{5}$. Wśród demokratycznych wyróżnia się demokracje libe-

${ }^{1}$ R. Dahl, Demokracja i jej krytycy, przeł. S. Amsterdamski, Kraków 1995, s. 332.

2 W. Roszkowski, Najnowsza historia Polski 1980-2006, Warszawa 2007, s. 148.

3 A. Antoszewski, Modele demokracji przedstawicielskiej, [w:] Demokracje zachodnioeuropejskie. Analiza porównawcza, red. Antoszewski, R. Herbut, Wrocław 2008, s. 18.

${ }^{4}$ Ibidem.

5 A. Antoszewski, Współczesne teorie demokracji, [w:] Studia z teorii polityki, t. 2, red. A. Jabłoński, L. Sobkowiak, Wrocław 1997, s. 15. 
ralne. Należą do nich między innymi demokracje zachodnioeuropejskie ${ }^{6}$. Ponadto Sonia Alonso, John Keane oraz Wolfgang Merkel zauważyli, że wraz z nadejściem trzeciej fali demokratyzacji w niektórych państwach Europy Środkowo-Wschodniej (Gruzja), Azji (Tajlandia) oraz Ameryki Łacińskiej (Brazylia) narodził się kolejny model demokratycznego reżimu politycznego: demokracja nieliberalna ${ }^{7}$. W artykule podjęto próbę udzielenia odpowiedzi na pytanie, który model demokracji funkcjonował w Polsce po alternacji władzy, jaka dokonała się w 2015 roku w wyniku wyborów prezydenckich i parlamentarnych oraz powstania koalicyjnego rządu Prawo i Sprawiedliwość (dalej: PiS)-Polska Razem (dalej: PR)-Solidarna Polska (dalej: SP) z Beatą Szydło na czele aż do czasu jego dymisji. W okresie poprzedzającym powstanie rządu Szydło Polska była postrzegana przez naukowców jako państwo odnoszące znaczne sukcesy w procesie konsolidowania demokracji ${ }^{8}$, potrafiące stworzyć fundamenty demokracji liberalnej, które nowy rząd rzekomo - chciał zakwestionować ${ }^{9}$. Dotychczas nie zostały przeprowadzone badania naukowe na temat stanu demokracji w Polsce w okresie funkcjonowania rządu Szydło. Celem niniejszego artykułu jest wypełnienie luki badawczej w tym zakresie.

\section{Obszary różnicujące demokrację liberalną i demokrację nieliberalną}

Do elementów wspólnych demokracji liberalnej i demokracji nieliberalnej zalicza się cechy składające się na poliarchię pełną. Oba modele różnią się natomiast od siebie w pięciu obszarach: rządów prawa, kontroli działań rządu i parlamentu przez instytucje niezależne od władz państwowych, poziomu korupcji wśród elit politycznych, stopnia wolności mediów oraz ochrony praw mniejszości ${ }^{10}$.

Rządy prawa należy rozumieć jako „przestrzeganie prawa, gdy prawo jest ogólne, jawne, prospektywne, jasne, spójne, możliwe do spełnienia i stabilne"11. W demokracji nieliberalnej uchwalane prawo często nie spełnia tych warunków. Ponadto władze państwowe nie przestrzegają prawa, jeżeli nie leży to $\mathrm{w}$ ich interesie politycznym. W państwach, w których funkcjonuje demokracja liberalna, rządzący na ogół stosują się do zasad rządów prawa. W niektórych sytuacjach decydują się na ich łamanie. Dochodzi do tego jednak zdecydowanie rzadziej niż w demokracjach nieliberalnych.

W ramach liberalnej demokracji działają instytucje niezależne od władz państwowych (sądy powszechne, Sąd Najwyższy, Trybunał Konstytucyjny), które są władne skazywać polityków partii rządzącej łamiących prawo oraz uchylać decyzje polityczne

${ }^{6}$ A. Antoszewski, Modele demokracji..., s. 17.

7 S. Alonso, J. Keane, W. Merkel, Editors' introduction: Rethinking the future of representative democracy, [w:] The Future of Representative Democracy, red. S. Alonso, J. Keane, W. Merkel, Cambridge 2011, s. 11.

8 A. Antoszewski, Demokratyzacja w Polsce w świetle wspótczesnej tranzytologii, [w:] Dylematy polskiej demokracji, red. Ł. Danel, J. Kornaś, Kraków 2012, s. 32.

9 A. Dudek, Historia polityczna Polski 1989-2015, Kraków 2016, s. 692.

10 S. Alonso, J. Keane, W. Merkel, op. cit., s. 11.

11 I. Sánchez-Cuenca, Władza, normy i podporzadkowanie, [w:] Demokracja i rzady prawa, red. J.M. Maravall, A. Przeworski, Warszawa 2010, s. 73. 
rządu i parlamentu, jeżeli są niezgodne z Konstytucją ${ }^{12}$. Rząd respektuje i implementuje ich decyzje. Jednocześnie rządy państw, w których funkcjonuje demokracja nieliberalna, nie uznają niesprzyjających dla nich decyzji podjętych przez niezależne organy. Często ograniczają ich kompetencje bądź przekształcają je w ciała lojalne wobec rządu (czynią to poprzez powołanie na ich członków osób blisko powiązanych z partią rządzącą) $)^{13}$.

W państwach, w których istnieje zarówno liberalna, jak i nieliberalna demokracja, występują przypadki korupcji wśród osób sprawujących najwyższe funkcje państwowe. Skala tego problemu jest wyraźnie mniejsza w tych drugich. Cechą charakterystyczną państwa, w którym funkcjonuje nieliberalna demokracja, jest wysoki poziom korupcji wśród członków partii politycznych ${ }^{14}$.

W liberalnych demokracjach działają w pełni wolne, pluralistyczne media kontrolujące działania rządzących i ujawniające afery polityczne, w które są oni zaangażowani. W państwach, w których istnieje nieliberalna demokracja, wolność mediów jest zaś częściowo ograniczona ${ }^{15}$. Media publiczne są kontrolowane przez rząd i pełnią funkcję propagandową. Znaczna część mediów prywatnych należy do osób powiązanych lub sympatyzujących z partią rządzącą. Wspierają one politykę rządu, za co są wynagradzane dodatkowymi przychodami pochodzącymi z reklam nabywanych przez przedsiębiorstwa państwowe. Niektóre media stosują autocenzurę (dobrowolnie rezygnują z krytyki rządu), aby zachęcić władze państwowe i zarządzane przez jej nominatów firmy do zakupu reklam. W ramach nieliberalnej demokracji działają również niezależne media pełniące funkcję kontrolną wobec rządu. Ich upadek bądź przejęcie przez rząd lub jego sojuszników spowodowałyby utratę dostępu do alternatywnych źródeł informacji przez obywateli - czyli jednego z elementów tworzących demokratyczne państwo - i oznaczałby, że w państwie doszło do transformacji reżimu politycznego z demokratycznego na niedemokratyczny.

Ochrona praw mniejszości narodowych, etnicznych i seksualnych należy do cech konstytutywnych liberalnej demokracji. Prawa mniejszości do praktykowania własnej religii, uczenia i posługiwania się rodzimym językiem oraz eksponowania kultury są chronione aktami prawnymi ${ }^{16}$. Instytucje państwa skutecznie bronią praw mniejszości w życiu codziennym. W demokracjach nieliberalnych zaś mniejszości są narażone na dyskryminację. Nie są chronione przepisami prawa lub mają wielkie problemy z ich egzekwowaniem.

W dalszej części pracy porównany zostanie stan demokracji w Polsce w obszarach różnicujących demokrację liberalną i demokrację nieliberalną w okresie funkcjonowania rządu PiS-PR-SP z premier Szydło oraz drugiego rządu Donalda Tuska (18 listopada 2011-22 września 2014 roku) i rządu Ewy Kopacz (22 września 2014-16 listopada 2015 roku), tworzonych przez Platformę Obywatelską (dalej: PO) i Polskie Stronnictwo Ludowe (dalej: PSL). Między rządami występowały relewantne jakościowe podobieństwa,

12 L. Diamond, Consolidating democracy, [w:] Comparing Democracies 2: New Challenges in the Study of Elections and Voting, red. L. LeDuc, R. Niemi, P. Norris, Londyn 2002, s. 213.

13 W. Merkel, Embedded and defective democracies, „Democratization” 11, 2004, nr 5, s. 49.

14 S. Alonso, J. Keane, W. Merkel, op. cit., s. 11.

15 Ibidem.

16 L. Diamond, op. cit., s. 213. 
które umożliwiały zastosowanie metody porównawczej ${ }^{17}$. Dysponowały one takimi samymi możliwościami (stabilna większość w parlamencie, przychylność prezydenta) oraz stawały przed tożsamymi ograniczeniami (wynikającymi z zapisów Konstytucji RP i członkostwa w Unii Europejskiej) w zakresie zarządzania państwem.

\section{Rządy prawa w Polsce}

Można wskazać znaczne różnice $\mathrm{w}$ zakresie przestrzegania zasad rządów prawa między koalicją rządową PiS-PR-SP z premier Szydło a rządem Kopacz i drugim rządem Tuska. Po pierwsze, koalicja PiS-PR-SP jako jedyna spośród badanych podejmowała się prób odwołania członków konstytucyjnego organu wybranych zgodnie z zasadami rządów prawa. Sejm RP głosami koalicji PiS-PR-SP przyjął 25 listopada 2015 roku uchwały unieważniające wybór pięciu sędziów Trybunału Konstytucyjnego (dalej: TK) (legalność wyboru trzech $\mathrm{z}$ nich potwierdził TK w swoim orzeczeniu z 3 grudnia $2015 \mathrm{roku}^{18}$ ), a 2 grudnia 2015 roku powołał na ich miejsce sędziów popieranych przez koalicję rządzącą.

Po drugie, jedyna ustawa w całości uchylona przez TK między 2011 a 2017 rokiem ze względu na jej brak zgodności z Konstytucją została przyjęta przez koalicję PiS-PR-SP. Była to ustawa z 22 grudnia 2015 roku o TK, której faktycznym celem było uniemożliwienie TK sprawowania funkcji kontrolnej nad działalnością rządu ${ }^{19}$.

Po trzecie, koalicję PiS-PR-SP cechował wysoki poziom braku stabilności w zakresie stanowienia prawa, a także retroaktywny charakter uchwalanych przez nią ustaw regulujących działanie instytucji kontrolnych. O braku stabilności prawa świadczy to, że w ciągu roku (od listopada 2015 do listopada 2016 roku) koalicja PiS-PR-SP uchwaliła osiem ustaw regulujących sposób funkcjonowania TK: trzy ustawy o TK, trzy ustawy o statusie sędziów TK oraz dwie ustawy o organizacji i trybie postępowania przed TK ${ }^{20}$. Przejawem retroaktywności prawa były między innymi przepisy ustawy o Sądzie Najwyższym (dalej: SN) skracające kadencję Pierwszego Prezesa Sądu Najwyższego, które odnosiły się do osoby powołanej na to stanowisko przed wejściem ustawy w życie ${ }^{21}$. Do takich sytuacji nie dochodziło w okresie działania drugiego rządu Tuska i rządu Kopacz.

Po czwarte, spośród analizowanych rządów Komisja Europejska (dalej: KE) wszczęła procedurę monitorowania praworządności tylko w stosunku do gabinetu Szydło. W jej ramach KE przyjęła opinię zawierającą zastrzeżenia wobec rządu polskiego w zakresie przestrzegania rządów prawa w Polsce (między innymi w kwestii dotyczącej zaprzysiężenia do TK trzech legalnie wybranych sędziów ${ }^{22}$ ).

17 A. Chodubski, Wstęp do badań politologicznych, Gdańsk 2006, s. 125-126.

18 Wyrok z 3 grudnia 2015 r. w sprawie zgodności z Konstytucją ustawy o Trybunale Konstytucyjnym, http://trybunal.gov.pl/postepowanie-i-orzeczenia/wyroki/art/8748ustawa-o-trybunale-konstytucyjnym/ (dostęp: 1.09.2018).

19 Zob. podrozdział Niezależne instytucje kontrolne w Polsce.

20 Strona internetowa Sejmu RP, http://www.sejm.gov.pl (dostęp: 1.09.2018).

${ }^{21}$ Zob. podrozdział Niezależne instytucje kontrolne $w$ Polsce.

${ }^{22}$ Komisja Europejska, Komunikat prasowy $z$ dnia 1 czerwca 2016 http://europa.eu/rapid/press-release_IP-16-2015_pl.htm (dostęp: 1.09.2018). 
Po piąte, jedynie w przypadku ustaw uchwalanych przez koalicję PiS-PR-SP Komisja Wenecka (dalej: KW) — organ doradczy Rady Europy — wydawała opinie, w których wskazywała, że zagrażają one rządom prawa i funkcjonowaniu systemu demokratycznego (ustawa z 22 grudnia 2015 roku o TK ${ }^{23}$ ) oraz są zagrożeniem niezależności systemu sądownictwa, będącego zdaniem KW kluczowym elementem rządów prawa (ustawa o SN i ustawa Prawo o ustroju sądów powszechnych) ${ }^{24}$.

W latach 2011-2015 również dochodziło do przypadków naruszania zasad rządów prawa. W okresie działania drugiego rządu Tuska koalicja PO-PSL przyjęła dziewięć aktów prawnych, a w trakcie funkcjonowania rządu Kopacz pięć ustaw, które częściowo zostały zakwestionowane przez $\mathrm{TK}^{25}$. Uchylone artykuły nie zmieniały ich ogólnego sensu. Wyroki TK dotyczyły jedynie spraw technicznych bądź też kwestii pobocznych polityk regulowanych przez te akty prawne. Wyjątek stanowiła ustawa o TK uchwalona w okresie funkcjonowania rządu Kopacz. Trybunał Konstytucyjny w orzeczeniu dotyczącym tego dokumentu nakazał uchylenie kluczowego z punktu widzenia ustawodawcy art. 137.1 ustawy $^{26}$, umożliwiającego Sejmowi VII kadencji wybór dwóch sędziów do TK w miejsce sędziów, których kadencja kończyła się w okresie funkcjonowania Sejmu VIII kadencji. Przepis ten miał pozwolić koalicji PO-PSL, dysponującej bezwzględną większością głosów w Sejmie VII kadencji, na powołanie do TK dwóch popieranych przez nią kandydatów.

W podrozdziale wykazano, że doszło do znacznej zmiany w obszarze przestrzegania rządów prawa w Polsce po alternacji władzy, jaka dokonała się w 2015 roku. W okresie poprzedzającym przejęcie władzy przez koalicję PiS-PR-SP w zakresie rządów prawa Polska przypominała - pomimo pojawiających się nadużyć, zwłaszcza w przypadku rządu Kopacz - inne demokracje liberalne. Już w kilka miesięcy po powstaniu rządu Szydło Polska zaczęła spełniać warunki typowe dla demokracji nieliberalnej w obszarze rządów prawa.

\section{Niezależne instytucje kontrolne w Polsce}

W okresie funkcjonowania rządu Szydło koalicja PiS-PR-SP uchwaliła ustawy uniemożliwiające realne sprawowanie funkcji kontrolnej nad działaniami władz państwowych przez niezależne organy konstytucyjne oraz przyjęła ustawy pozwalające na wymianę osób wchodzących w ich skład. Do pierwszego typu aktów prawnych można zaliczyć ustawę z 22 grudnia 2015 roku o TK. Nakładała ona na TK obowiązek rozpatrywania wniosków do tej instytucji według kolejności zgłoszeń. Wcześniej to TK samodzielnie decydował, które wnioski będzie rozpatrywał w danym terminie. Zgodnie z nową usta-

23 Komisja Wenecka, Opinia w sprawie nowelizacji ustawy z dnia 25 czerwca 2015 r. o Trybunale Konstytucyjnym, s. 22, http://www.hfhr.pl/wp-content/uploads/2016/03/ HFPC_opinia_komisja_wenecka_tlumaczenie_PL.pdf (dostęp: 1.09.2018).

24 Komisja Wenecka, Opinion on the draft act amending the act on the national council of the judicary, on the draft act on the supreme court, proposed by the President of Poland, and on the act on the organisation of ordinary courts, s. 26, http://www.venice.coe.int/webforms/documents/default.aspx?pdffile=CDL$\mathrm{AD}$ (2017)031-e (dostęp: 1.09.2018).

25 Strona internetowa Trybunału Konstytucyjnego, http://trybunal.gov.pl/ (dostęp: 1.09.2018).

26 Wyrok z 3 grudnia 2015 r. w sprawie zgodności z Konstytucją ustawy o Trybunale Konstytucyjnym. 
wą większość wniosków (w tym te, które dotyczyły zgodności ustaw z konstytucją) miała być rozpatrywana w pełnym składzie TK (ustawa zmieniała definicję pełnego składu: z co najmniej dziewięciu na minimum trzynastu sędziów). Poprzednie regulacje zezwalały TK na rozstrzyganie zgodności ustaw z konstytucją w składzie pięciu sędziów ${ }^{27}$. Zmiany te miały na celu spowolnienie prac TK, tak aby mógł on badać zgodność ustaw przyjętych przez koalicję PiS-PR-SP z Konstytucją dopiero kilka lat po ich uchwaleniu.

Ustawa z 22 grudnia 2015 roku o TK weszła w życie w dniu opublikowania w Dzienniku Ustaw. Z tego powodu TK nie mógł zweryfikować jej zgodności z Konstytucją, działając na podstawie poprzedniej ustawy o TK. Sędziowie TK uznali, że rozpatrzą wniosek o stwierdzenie zgodności z Konstytucją nowej ustawy, stosując wprost przepisy Konstytucji. Rząd Szydło odmówił implementowania wyroku TK uchylającego tę ustawę, twierdząc, że wyrok zapadł w trybie niezgodnym z obowiązującym w Polsce stanem prawnym ${ }^{28}$. Nie był to jedyny przypadek bojkotowania wyroków TK przez koalicję PiS-PR-SP. Odmówiła ona między innymi wykonania dwóch wyroków TK, które zapadły jeszcze przed wejściem w życie ustawy z 22 grudnia 2015 roku o TK ${ }^{29}$. W grudniu 2016 roku prezydent Andrzej Duda w miejsce kończącego kadencję sędziego Andrzeja Rzeplińskiego powołał na stanowisko przewodniczącego TK sędziego nominowanego przez koalicję PiS-PR-SP, Julię Przyłębską. Decyzja ta zakończyła proces podporządkowywania sobie TK przez koalicję rządową ${ }^{30}$.

W lipcu 2017 roku koalicja PiS-PR-SP wprowadziła zmiany do ustawy Prawo o ustroju sądów powszechnych nadające dodatkowe uprawnienia ministrowi sprawiedliwości. Na ich podstawie minister mógł arbitralnie podjąć decyzję o odwołaniu każdego prezesa sądu powszechnego, a także samodzielnie mianować $\mathrm{w}$ ich miejsce preferowanych przez siebie sędziów ${ }^{31}$ (zgodnie z obowiązującymi wcześniej regulacjami samorząd sędziowski i Krajowa Rada Sądownictwa mogły blokować decyzje ministra sprawiedliwości w tym zakresie $^{32}$ ). Prezesi sądów także otrzymali nowe uprawnienia - mogli bez podania przyczyn przenieść sędziów do innych wydziałów. W ten sposób sędziowie nieprzychylni władzy mogli szybko zostać zmarginalizowani. Z nowych kompetencji wielokrotnie skorzystał minister sprawiedliwości Zbigniew Ziobro. Pomiędzy sierpniem a grudniem 2017 roku wymienił sześćdziesięciu dwóch prezesów sądów powszechnych ${ }^{33}$.

Zasadniczym celem ustawy z dnia 8 grudnia 2017 roku o SN było umożliwienie wymiany członków tych organów. Ustawa o SN obniżała wiek emerytalny wszystkim

27 Komisja Wenecka, Opinia w sprawie nowelizacji ustawy z dnia 25 czerwca 2015 r. o Trybunale Konstytucyjnym, s. 8-15.

28 P. Arak, A. Bobiński, Nations in transit 2017. Poland, https://freedomhouse.org/report/nations-transit/2017/poland, s. 10 (dostęp: 1.09.2018).

29 Chodzi o wyroki TK z 3 i 9 grudnia 2015 r. w sprawie ustaw o TK.

30 A. Wójcik, Nations in transit 2018. Poland, s. 11, https://freedomhouse.org/report/nations-transit/2018/poland (dostęp: 1.09.2018).

31 Ibidem.

32 Art. 23 i art. 24 ustawy z dnia 27 lipca 2001 r. Prawo o ustroju sądów powszechnych, Dz.U. z 2001 r. Nr 98, poz. 1070.

33 Ibidem. 
sędziom należącym do SN z 70. do 65. roku życia. Regulacje te obejmowały także Pierwszego Prezesa Sądu Najwyższego, Małgorzatę Gersdorf, wybraną - zgodnie z Konstytucją $^{34}$ - na sześcioletnią kadencję w 2014 roku. Według przepisów nowej ustawy o SN Małgorzata Gersdorf powinna przestać sprawować funkcję Pierwszego Prezesa Sądu Najwyższego wraz z osiągnięciem 65. roku życia w 2018 roku, mimo że jej kadencja wygasa w kwietniu 2020 roku.

Warto odnotować, że zgodnie z ustawą o SN sędziowie SN, którzy osiągnęli 65. rok życia, mogli pozostać w SN, jeżeli uzyskali na to zgodę od prezydenta ${ }^{35}$. Uzależnienie prawa do dalszego zasiadania w SN od decyzji politycznej podważa autonomię sędziów SN i umożliwia prezydentowi pozbycie się nieprzychylnych osób z tej instytucji.

W okresie działania rządu Szydło koalicja PiS-PR-SP przyjęła ustawy dające narzędzia do zmarginalizowania bądź przejęcia niezależnych instytucji kontrolnych przez obóz władzy $^{36}$. Tego rodzaju regulacje nie były wprowadzane przez PO-PSL w trakcie funkcjonowania drugiego rządu Tuska i rządu Kopacz ${ }^{37}$. Oba rządy PO-PSL respektowały wyroki TK. Nie dążyły również do ograniczenia kompetencji instytucji kontrolnych ani do skrócenia kadencji ich członków. Nie ulega wątpliwości, że w zakresie sprawowania funkcji kontrolnej nad działaniami władz państwowych przez niezależne instytucje Polska w latach 2011-2015 mieściła się w granicach demokracji liberalnej. W latach 2015-2017 Polska przeszła transformację w kierunku demokracji nieliberalnej w tym obszarze.

\section{Poziom korupcji wśród elit politycznych}

W celu określenia stopnia skorumpowania elit politycznych w Polsce w latach 20122017 odwołano się do wyników badań przeprowadzanych przez Transparency International w około 170 państwach w zakresie postrzeganej w nich korupcji wśród najwyższych urzędników państwowych. Autorzy badań definiowali korupcję jako nadużywanie władzy publicznej dla prywatnych zysków ${ }^{38}$.

Każde z państw mogło w badaniach uzyskać od 0 do 100 punktów. Wraz ze wzrostem liczby punktów spada poziom postrzeganej korupcji w państwie ${ }^{39}$. Państwa widziane jako skorumpowane w mniejszym stopniu uzyskują wyniki w przedziale 51-100 punktów, natomiast te, które są uważane za skorumpowane $\mathrm{w}$ większym stopniu - w przedziale $0-50$ punktów. W tabeli 1 przedstawiono wyniki osiągnięte przez Polskę w latach 2012-2017.

34 Art. 183 Konstytucji RP, http://www.sejm.gov.pl/prawo/konst/polski/kon1.htm (dostęp: 1.09.2018).

35 A. Wójcik, op. cit., s. 13.

36 Do momentu upadku rządu Szydło koalicja PiS - PR - SP zdążyła dokonać zmian personalnych w TK i sądach powszechnych.

37 Z wyjątkiem ustawy z dnia 25 czerwca 2015 r. o TK.

38 Transparency International, Corruption Perceptions Index 2010, Long Methodological Brief, http:// transparency.ee/cm/files/cpi2010_long_methodology_en.pdf (dostęp: 1.09.2018).

39 Ibidem. 
Tabela 1. Poziom postrzeganej korupcji w Polsce w latach 2012-2017

\begin{tabular}{c|c}
\hline Rok & Liczba uzyskanych punktów \\
\hline 2012 & 58 \\
\hline 2013 & 60 \\
\hline 2014 & 61 \\
\hline 2015 & 63 \\
\hline 2016 & 62 \\
\hline 2017 & 60 \\
\hline
\end{tabular}

Źródło: opracowanie własne na podstawie Transparency International, Corruption Perceptions Index 2017, https:// www.transparency.org/news/feature/corruption_perceptions_index_2017 (dostęp: 1.09.2018).

Na podstawie wyników badań zaprezentowanych w tabeli 1 można stwierdzić, że w trakcie działania drugiego rządu Tuska, rządu Kopacz oraz rządu Szydło Polska znajdowała się wśród państw postrzeganych jako skorumpowane w mniejszym stopniu. Uzyskiwała bowiem więcej niż 50 punktów (58-63 punkty) w latach 2012-2017.

W trakcie istnienia każdego $\mathrm{z}$ gabinetów wybuchały afery korupcyjne, w które zaangażowani byli członkowie partii rządzących (np. afera Amber Gold, afera zegarkowa, „the Waitergate” w okresie funkcjonowania drugiego rządu Tuska i rządu Kopacz ${ }^{40}$ czy też przypadki nepotyzmu oraz działań o znamionach korupcyjnych w związku z obsadzaniem stanowisk w spółkach Skarbu Państwa w okresie aktywności rządu Szydło ${ }^{41}$ ). Warto jednak podkreślić, że w każdym demokratycznym państwie pojawiają się afery korupcyjne. Przytoczone wyniki badań jednoznacznie wskazują, że Polska w latach 2012-2017 spełniała kryteria demokracji liberalnej w zakresie poziomu korupcji występującej wśród elit władzy.

\section{Wolność mediów w Polsce}

Przy określaniu stopnia wolności mediów w Polsce powołano się na wyniki corocznych badań z cyklu „Freedom of the Press,” prowadzonych przez Freedom House ${ }^{42}$, a dotyczących zakresu wolności mediów w ponad 180 państwach. Są one opracowywane na podstawie badań terenowych, rozmów z ekspertami oraz raportów przygotowanych przez NGO i międzynarodowe instytucje, które dotyczą ekonomicznego, prawnego i politycznego środowiska medialnego ${ }^{43}$.

40 P. Arak, P. Żakowiecki, Nations in transit 2015. Poland, s. 494-495, https://freedomhouse.org/report/ nations-transit/2015/poland (dostęp: 1.09.2018).

41 P. Arak, A. Bobiński, op. cit., s. 11.

42 Niezależna amerykańska organizacja non-profit działająca na rzecz rozwoju demokracji i wolności na świecie.

43 Strona internetowa Freedom House, https://freedomhouse.org/report/freedom-press-2017-methodology (dostęp: 1.09.2018). 
W badaniach każde z państw mogło otrzymać od 0 do 100 punktów. Stopień „wolne media" jest przyznawany państwom, które dostały 0-30 punktów, natomiast stopień „częściowo wolne media” państwom otrzymującym 31-60 punktów. Media uznane za niewolne działają w państwach, które uzyskały 61-100 punktów ${ }^{44}$.

Wyniki badań dla Polski dotyczące stopnia wolności mediów w latach 2012-2016 ${ }^{45}$ znajdują się w tabeli 2.

Tabela 2. Stopień wolności mediów w Polsce w latach 2012-2016

\begin{tabular}{c|c|c}
\hline Badany rok & $\begin{array}{c}\text { Liczba zdobytych punktów } \\
\text { w badaniach Freedom of the Press }\end{array}$ & $\begin{array}{c}\text { Stopień wolności } \\
\text { mediów }\end{array}$ \\
\hline 2012 & 26 & Wolne media \\
\hline 2013 & 27 & Wolne media \\
\hline 2014 & 26 & Wolne media \\
\hline 2015 & 28 & Częściowo wolne media \\
\hline 2016 & 34 &
\end{tabular}

Źródło: opracowanie własne na podstawie Freedom House, Freedom of the Press 2013, 2014, 2015, 2016, 2017, https:// freedomhouse.org/report/freedom-press (dostęp: 1.09.2018).

Z tabeli 2 wynika, że Polska w latach 2012-2015 była zaliczana do grona państw, w których działały wolne media. Po roku funkcjonowania rządu Szydło Polska została zaklasyfikowana do grupy państw, w których media są jedynie częściowo wolne. Można wyróżnić dwie przyczyny uzasadniające taki zwrot. Pierwsza z nich dotyczy zmiany sposobu zarządzania mediami publicznymi. Koalicja PiS-PR-SP uchwaliła nowelizację ustawy o radiofonii i telewizji natychmiastowo wygaszającą mandaty członków rad nadzorczych i zarządów mediów publicznych. Ustawa przyznawała Ministrowi Skarbu kompetencje powoływania członków tych ciał bez potrzeby organizowania konkursów ${ }^{46}$. W ciągu czterech miesięcy od mianowania nowych władz mediów publicznych (styczeń-kwiecień 2016) ponad 140 pracowników odeszło z pracy bądź zostało z niej zwolnionych ${ }^{47}$. Konsekwencją tych zmian było przekształcenie się mediów publicznych w organy silnie wspierające rząd, które zwalczają opozycję i liberalne organizacje pozarządowe $^{48}$. Telewizja oraz radio publiczne sprzyjały władzom państwowym również w okresie funkcjonowania drugiego rządu Tuska i rządu Kopacz. Skala upolitycznienia mediów była jednak znacznie mniejsza niż w okresie działania rządu Szydło ${ }^{49}$.

44 Ibidem.

$45 \mathrm{~W}$ trakcie przygotowywania artykułu raport za 2017 rok nie był dostępny.

46 W okresie funkcjonowania drugiego rządu Tuska i rządu Kopacz to KRRiT (organ konstytucyjny) była odpowiedzialna za wybór członków rad nadzorczych i zarządów mediów publicznych w drodze konkursu, w którym mogły wziąć udział osoby zgłoszone przez organy kolegialne uczelni wyższych.

47 Freedom House, Freedom of the Press 2017, https://freedomhouse.org/report/freedom-press/2017/ poland (dostęp: 1.09.2018).

48 A. Wójcik, op. cit., s. 3, 9-10.

49 Freedom House, Freedom... 
Rząd Szydło dążył do ograniczenia dochodów mediów prywatnych sprzyjających opozycji. Większość instytucji publicznych odwołała prenumeratę gazet i czasopism nastawionych krytycznie do rządu, spółki Skarbu Państwa zaprzestały zaś kupowania reklam w mediach przyjaznych opozycji na rzecz mediów prorządowych ${ }^{50}$. Ponadto, minister kultury i dziedzictwa narodowego Piotr Gliński przyznawał dotacje jedynie czasopismom sympatyzującym z koalicją PiS-PR-SP, odmówił zaś udzielenia wsparcia magazynom lewicowo-liberalnym („Przeglądowi Politycznemu”, „Liberte!” i „Krytyce Politycznej”). ${ }^{51} \mathrm{~W}$ rezultacie tych działań w Polsce pojawily się liczne przypadki autocenzury wśród przedstawicieli mediów ogólnokrajowych i lokalnych kojarzonych z opozycją ${ }^{52}$. Należy zaznaczyć, że - rzadziej i tylko w przypadku mediów lokalnych — do takich incydentów dochodziło w okresie działania drugiego rządu Tuska i rządu $\mathrm{Kopacz}^{53}$.

W okresie istnienia rządu Szydło (oraz drugiego rządu Tuska i rządu Kopacz) na polskim rynku medialnym działały dobrze rozwinięte media sprzyjające koalicji PiSPR-SP (na przykład media publiczne, TV Trwam, „Rzeczpospolita”, „Gość Niedzielny”, „Nasz Dziennik”, „Gazeta Polska” ${ }^{44}$ ) oraz sympatyzujące z opozycją (na przykład TVN 24, „Gazeta Wyborcza”, „Polityka”, „Newsweek”55). Dostępne były także apolityczne tabloidy i czasopisma o profilu biznesowym ${ }^{56}$. Bez wątpienia obywatele Polski mieli dostęp do alternatywnych źródeł informacji w latach 2011-2017.

Ze względu na wrogą politykę rządu Szydło w stosunku do mediów opozycyjnych Polska zaczęła spełniać kryteria typowe dla demokracji nieliberalnej w zakresie wolności mediów. W czasie działania drugiego rządu Tuska i rządu Kopacz Polska była demokracją liberalną w tym zakresie.

\section{Ochrona praw mniejszości w Polsce}

W Polsce prawa mniejszości narodowych i etnicznych do zachowania obyczajów i tradycji oraz rozwoju własnej kultury i języka są zagwarantowane w Konstytucji RP ${ }^{57}$. Drugi rząd Tuska, rząd Kopacz i rząd Szydło respektowały te prawa. W okresie działania każ-

50 W ciągu pierwszego półrocza 2016 roku (w porównaniu do pierwszego półrocza 2015 roku) czasopisma sprzyjające rządowi zwiększyły dochody z tytułu reklam między 33\% („W Sieci”) a 287\% („Gazeta Polska”). W tym samym czasie dochody największej gazety opozycyjnej („Gazeta Wyborcza”) z tytułu reklam spadły o $21 \%$ - P. Arak, A. Bobiński, op. cit., s. 8-9.

51 Ibidem, s. 8.

52 Freedom House, Freedom...

53 Ibidem.

${ }^{54}$ Freedom of the House, Freedom of the Press 2016, https://freedomhouse.org/report/freedom-press/2016/ poland (dostęp: 1.09.2018).

55 Ibidem.

56 Ibidem.

57 Art. 35 Konstytucji RP. 
dego z nich instytucje państwowe finansowały szkoły dwujęzyczne, programy telewizyjne i radiowe oraz książki i periodyki w językach mniejszości ${ }^{58}$.

Trzeba jednak zaznaczyć, że w latach 2012-2017 wyraźnie zwiększyła się liczba przestępstw popełnianych z pobudek rasistowskich, antysemickich lub ksenofobicznych, których ofiarami byli przedstawiciele mniejszości narodowych i etnicznych (w szczególności Romowie i Żydzi) oraz muzułmanie ${ }^{59}$. W 2012 roku prowadzono 473 postępowania z pobudek rasistowskich, antysemickich lub ksenofobicznych (wyroki skazujące zapadły wobec 59 osób) ${ }^{60}$. Liczba postępowań systematycznie rosła przez kolejne cztery lata. W 2016 roku wyniosła 1631 (wyroki skazujące zapadły wobec 241 osób) ${ }^{61}$. W 2017 roku nastąpił niewielki spadek - prowadzono wówczas 1449 postępowań (wyroki skazujące zapadły wobec 420 osób) ${ }^{62}$. Wzrost liczby przestępstw wobec przedstawicieli mniejszości należy tłumaczyć nasileniem się postaw ksenofobicznych wśród Polaków w latach 2011-2015 (liczba osób o nastawieniu ksenofobicznym zwiększyła się o jedną czwartą, z $26,5 \%$ do $32,3 \%)^{63}$. Warto podkreślić, że zaprezentowane dane dotyczące liczby przestępstw popełnianych z pobudek rasistowskich, antysemickich lub ksenofobicznych są wysoce niedoszacowane. Zgodnie z wynikami badań przeprowadzonych przez Biuro Rzecznika Praw Obywatelskich „jedynie 5\% przestępstw motywowanych nienawiścią jest zgłaszanych na policję przez pokrzywdzonego lub inną osobę" 64 .

Koalicja PO-PSL podjęła działania mające na celu ograniczenie dyskryminacji na tle rasowym i etnicznym. Drugi rząd Tuska powołał do życia Radę do spraw Przeciwdziałania Dyskryminacji Rasowej, Ksenofobii i związanej z nimi Nietolerancji, której zadaniem było poprawienie poziomu współpracy między instytucjami publicznymi w zakresie zwalczania

58 Freedom House, Freedom in the World 2014, https://freedomhouse.org/report/freedom-world/2014/ poland (dostęp: 1.09.2018).

59 Prokuratura Krajowa, Wyciag ze sprawozdania dotyczacego spraw prowadzonych w 2016 r. $w$ jednostkach organizacyjnych prokuratury z pobudek rasistowskich lub ksenofobicznych, s. 20, https://pk.gov.pl/ dzialalnosc/sprawozdania-i-statystyki/wyciag-ze-sprawozdania-dot-spraw-o-przestepstwa-popelnione-zpobudek-rasistowskich-antysemickich-lub-ksenofobicznych-prowadzonych-w-2016-roku-w-jednostkach-organizacyjnych-prokuratury/ (dostęp: 1.09.2018).

60 Prokuratura Krajowa, Wyciag ze sprawozdania dotyczacego spraw prowadzonych $w 2012 \mathrm{r}$. $w$ jednostkach organizacyjnych prokuratury z pobudek rasistowskich lub ksenofobicznych, s. 1, 10, https://pk.gov.pl/ dzialalnosc/sprawozdania-i-statystyki/sprawy-z-pobudek-rasistowskich-lub-ksenofobicznych-w-2012-r/ (dostęp: 1.09.2018).

61 Prokuratura Krajowa, Wyciag ze sprawozdania dotyczacego spraw prowadzonych $w 2016 \mathrm{r}$. $w$ jednostkach organizacyjnych prokuratury z pobudek rasistowskich lub ksenofobicznych, s. 1, 24.

62 Prokuratura Krajowa, Wyciag ze sprawozdania dotyczacego spraw prowadzonych $w 2017$ r. $w$ jednostkach organizacyjnych prokuratury z pobudek rasistowskich lub ksenofobicznych, s. 1, 5, https://pk.gov.pl/ dzialalnosc/sprawozdania-i-statystyki/wyciag-ze-sprawozdania-dot-spraw-o-przestepstwa-popelnione-zpobudek-rasistowskich-antysemickich-lub-ksenofobicznych-prowadzonych-w-2017-roku-w-jednostkach-organizacyjnych-prokuratury/ (dostęp: 1.09.2018).

${ }_{63}$ Diagnoza Społeczna 2015, red. J. Czapiński, T. Panek, Warszawa 2015, s. 367-368.

64 Biuro Rzecznika Praw Obywatelskich, Jedynie 5\% przestępstw motywowanych nienawiścia jest zgłaszanych na policje - badania RPO i ODIHR/OBWE, https://www.rpo.gov.pl/pl/content/jedynie-5-przestepstw-motywowanych-nienawiscia-jest-zglaszanych-na-policje-badania-rpo-i-odihrobwe (dostęp: 1.09.2018). 
dyskryminacji rasowej i ksenofobii. W 2016 roku rząd Szydło podjął decyzję o likwidacji tego ciała. Sekretarz Stanu w Kancelarii Prezesa Rady Ministrów, Wojciech Kaczmarczyk, motywował ją niską efektywnością działania instytucji ${ }^{65}$. Rząd Szydło nie stworzył alternatywnych mechanizmów służących ograniczeniu przejawów dyskryminacji.

Osoby LGBTQI są obiektem licznych ataków w Polsce. Z badań przeprowadzonych przez World Values Survey na reprezentatywnej grupie osób LGBTQI wynika, że między 2010 a 2015 rokiem aż 29,3\% ich uczestników „doświadczyło przemocy fizycznej $\mathrm{i} /$ lub psychicznej motywowanej nienawiścią" ${ }^{66}$. Dane te nie wpłynęły na politykę rządów PO-PSL i PiS-PR-SP, które nie zdecydowały się — mimo apeli ze strony największych w Europie organizacji LGBTQI ${ }^{67}$ - na zaliczenie tego typu przestępstw do grupy przestępstw popełnianych $\mathrm{z}$ nienawiści.

W Polsce w latach 2012-2017 doszło do radykalnego wzrostu liczby przestępstw popełnianych z pobudek rasistowskich, antysemickich lub ksenofobicznych. Jeszcze częściej niż w przypadku mniejszości narodowych i etnicznych na agresję były narażone osoby LGBTQI. Można zatem stwierdzić, że Polska była bliższa wzorcom typowym dla demokracji nieliberalnej niż liberalnej w zakresie ochrony praw mniejszości w okresie działania drugiego rządu Tuska, rządu Kopacz i rządu Szydło, mimo że przedstawiciele niektórych mniejszości (czyli narodowych i etnicznych) uzyskiwali wsparcie finansowe od instytucji państwowych.

\section{Podsumowanie}

W trakcie funkcjonowania rządu Szydło doszło w Polsce do transformacji reżimu politycznego z demokracji liberalnej na demokrację nieliberalną. Świadczy o tym fakt, że w przypadku trzech spośród pięciu obszarów różnicujących demokrację liberalną i nieliberalną rząd Szydło odrzucił wzorce typowe dla tego pierwszego modelu demokracji na rzecz właściwych dla demokracji nieliberalnej. Chodzi tutaj o rządy prawa, kontrolę działań rządu i parlamentu przez niezależne od władz państwowych instytucje oraz wolność mediów. Trzeba zaznaczyć, że zarówno w okresie działania drugiego rządu Tuska, jak i rządu Kopacz Polska przestrzegała zasad demokracji liberalnej we wskazanych zakresach.

Ponadto Polskę można było zaliczyć do demokracji nieliberalnych w zakresie ochrony praw mniejszości narodowych, etnicznych i seksualnych w okresie funkcjonowania każdego z analizowanych rządów. W okresie działania rządu Szydło Polska spełniała

65 W. Kaczmarczyk, Odpowiedź na interpelację nr 3009 w sprawie zniesienia Rady do spraw Przeciwdziałania Dyskryminacji Rasowej, Ksenofobii i zwiąanej z nimi Nietolerancji, http://www.sejm.gov.pl/sejm8.nsf/ InterpelacjaTresc.xsp?key=1709BA7D (dostęp: 1.09.2018).

66 P. Górska et al., Raport o Polsce, Warszawa 2016, s. 18.

67 ILGA-Europe, Annual Review of the Human Rights Situation of Lesbian, Gay, Bisexual, Trans and Intersex People in Europe 2017, Bruksela 2017, s. 182. 
kryteria demokracji liberalnej jedynie w kwestii poziomu występowania korupcji wśród elit politycznych (Polskę można było zaliczyć do demokracji liberalnych w tym zakresie również w okresie działania drugiego rządu Tuska i rządu Kopacz). Nie zmienia to faktu, że w ciągu dwóch lat istnienia rządu Szydło reżim polityczny w Polsce przybrał postać demokracji nieliberalnej.

\section{Bibliografia}

Alonso S., Keane J., Merkel W., Editors' introduction: Rethinking the future of representative democracy, [w:] The Future of Representative Democracy, red. S. Alonso, J. Keane, W. Merkel, Wydawnictwo Uniwersytetu Cambridge, Cambridge 2011.

Antoszewski A., Demokratyzacja w Polsce w świetle współczesnej tranzytologii, [w:] Dylematy polskiej demokracji, red. Ł. Danel, J. Kornaś, Fundacja Gospodarki i Administracji Publicznej, Kraków 2012.

Antoszewski A., Modele demokracji przedstawicielskiej, [w:] Demokracje zachodnioeuropejskie. Analiza porównawcza, red. A. Antoszewski, R. Herbut, Wydawnictwo Uniwersytetu Wrocławskiego, Wrocław 2008.

Antoszewski A., Współczesne teorie demokracji, [w:] Studia z teorii polityki, t. 2, red. A. Jabłoński, L. Sobkowiak, Wydawnictwo Uniwersytetu Wrocławskiego, Wrocław 1997.

Arak P., Bobiński A., Nations in transit 2017. Poland, Freedom House, https://freedomhouse.org/report/ nations-transit/2017/poland (dostęp: 1.09.2018).

Arak P., Żakowiecki P., Nations in transit 2015. Poland, https://freedomhouse.org/report/nations-transit/2015/ poland (dostęp: 1.09.2018).

Biuro Rzecznika Praw Obywatelskich, Jedynie 5\% przestępstw motywowanych nienawiścia jest zgłaszanych na policje - badania RPO i ODIHR/OBWE, https://www.rpo.gov.pl/pl/content/jedynie-5-przestepstw-motywowanych-nienawiscia-jest-zglaszanych-na-policje-badania-rpo-i-odihrobwe (dostęp: 1.09.2018).

Chodubski, A., Wstęp do badań politologicznych, Wydawnictwo Uniwersytetu Gdańskiego, Gdańsk 2006.

Dahl R., Demokracja i jej krytycy, Znak, Kraków 1995.

Diagnoza Społeczna 2015, red. J. Czapiński, T. Panek, Rada Monitoringu Społecznego, Warszawa 2015.

Diamond L., Consolidating democracy, [w:] Comparing Democracies 2: New Challenges in the Study of Elections and Voting, red. L. LeDuc, R. Niemi, P. Norris, Sage Publications, Londyn 2002.

Dudek A., Historia polityczna Polski 1989-2015, Znak Horyzont, Kraków 2016.

Freedom House, Freedom in the World 2014, https://freedomhouse.org/report/freedom-world/2014/Poland (dostęp: 1.09.2018).

Freedom House, Freedom of the Press 2013, https://freedomhouse.org/report/freedom-Press (dostęp: 1.09.2018). Freedom House, Freedom of the Press 2014, https://freedomhouse.org/report/freedom-Press (dostęp: 1.09.2018). Freedom House, Freedom of the Press 2015, https://freedomhouse.org/report/freedom-press(dostęp: 1.09.2018). Freedom House, Freedom of the Press 2016, https://freedomhouse.org/report/freedom-Press (dostęp: 1.09.2018). Freedom House, Freedom of the Press 2017, https://freedomhouse.org/report/freedom-Press (dostęp: 1.09.2018). Górska P., Budziszewska M., Knut P., Łada P., Raport o Polsce, Kampania Przeciw Homofobii, Warszawa 2016. ILGA-Europe, Annual Review of the Human Rights Situation of Lesbian, Gay, Bisexual, Trans and Intersex People in Europe 2017, OLGA-Europe, Bruksela 2017.

Kaczmarczyk W., Odpowiedź na interpelację nr 3009 w sprawie zniesienia Rady do spraw Przeciwdziałania Dyskryminacji Rasowej, Ksenofobii i zwiąanej z nimi Nietolerancji, http://www.sejm.gov.pl/sejm8.nsf/ InterpelacjaTresc.xsp?key=1709BA7D (dostęp: 1.09.2018).

Komisja Europejska, Komunikat prasowy z dnia 1 czerwca 2016, http://europa.eu/rapid/press-release_IP-162015_pl.htm (dostęp: 1.09.2018).

Komisja Wenecka, Opinia w sprawie nowelizacji ustawy z dnia 25 czerwca 2015 r. o Trybunale Konstytu- 
cyjnym, http://www.hfhr.pl/wp-content/uploads/2016/03/HFPC_opinia_komisja_wenecka_tlumaczenie_PL.pdf.

Komisja Wenecka, Opinion on the draft act amending the act on the national council of the judicary, on the draft act on the supreme court, proposed by the President of Poland, and on the act on the organisation of ordinary courts, http://www.venice.coe.int/webforms/documents/default.aspx?pdffile=CDL-AD(2017)031-e (dostęp: 1.09.2018).

Konstytucja RP, http://www.sejm.gov.pl/prawo/konst/polski/kon1.htm (dostęp: 1.09.2018).

Merkel W., Embedded and defective democracies, „Democratization” 11, 2004, nr 5.

Prokuratura Krajowa, Wyciag ze sprawozdania dotyczacego spraw prowadzonych w 2012 r. w jednostkach organizacyjnych prokuratury z pobudek rasistowskich lub ksenofobicznych, https://pk.gov.pl/dzialalnosc/sprawozdania-i-statystyki/sprawy-z-pobudek-rasistowskich-lub-ksenofobicznych-w-2012-r/ (dostęp: 1.09.2018).

Prokuratura Krajowa, Wyciag ze sprawozdania dotyczacego spraw prowadzonych w $2016 r$. w jednostkach organizacyjnych prokuratury $z$ pobudek rasistowskich lub ksenofobicznych, https://pk.gov.pl/dzialalnosc/ sprawozdania-i-statystyki/wyciag-ze-sprawozdania-dot-spraw-o-przestepstwa-popelnione-z-pobudekrasistowskich-antysemickich-lub-ksenofobicznych-prowadzonych-w-2016-roku-w-jednostkach-organizacyjnych-prokuratury/ (dostęp: 1.09.2018).

Prokuratura Krajowa, Wyciag ze sprawozdania dotyczacego spraw prowadzonych $w$ 2017r. $w$ jednostkach organizacyjnych prokuratury $z$ pobudek rasistowskich lub ksenofobicznych, https://pk.gov.pl/dzialalnosc/ sprawozdania-i-statystyki/wyciag-ze-sprawozdania-dot-spraw-o-przestepstwa-popelnione-z-pobudekrasistowskich-antysemickich-lub-ksenofobicznych-prowadzonych-w-2017-roku-w-jednostkach-organizacyjnych-prokuratury/ (dostęp: 1.09.2018).

Roszkowski W., Najnowsza historia Polski 1980-2006, Świat Książki, Warszawa 2007.

Sánchez-Cuenca I., Władza, normy i podporządkowanie, [w:] Demokracja i rządy prawa, red. J.M. Maravall, A. Przeworski, Scholar, Warszawa 2010.

Strona internetowa Sejmu RP, http://www.sejm.gov.pl (dostęp: 1.09.2018).

Strona internetowa Trybunału Konstytucyjnego, http://trybunal.gov.pl/ (dostęp: 1.09.2018).

Transparency International, Corruption Perceptions Index 2017,

https://www.transparency.org/news/feature/corruption_perceptions_index_2017 (dostęp: 1.09.2018).

Transparency International, Corruption Perceptions Index 2010, Long Methodological Brief, http://transparency.ee/cm/files/cpi2010_long_methodology_en.pdf (dostęp: 1.09.2018).

Ustawa z dnia 27 lipca 2001 r. Prawo o ustroju sądów powszechnych, Dz.U. z 2001r. Nr 98, poz. 1070.

Wójcik A., Nations in transit 2018. Poland, https://freedomhouse.org/report/nations-transit/2018/poland (dostęp: 1.09.2018).

Wyrok z 3 grudnia 2015 r. w sprawie zgodności z Konstytucją ustawy o Trybunale Konstytucyjnym, http://trybunal. gov.pl/postepowanie-i-orzeczenia/wyroki/art/8748-ustawa-o-trybunale-konstytucyjnym/ (dostęp: 1.09.2018).

\section{Evolution of the political regime in Poland during the functioning of Beata Szydło's government}

Keywords: political regime, liberal democracy, illiberal democracy, the rule of law

\section{Summary}

Liberal and illiberal democracies can be defined on the basis of five criteria distinct in both types of democracy: the rule of law, the government's control, political elites' integrity, media freedom and minorities' protection. The article shows that four out of five criteria constituting illiberal democracy were fulfilled in Poland while Beata Szydło's government was functioning (the rule of law, the government's control, media freedom and minorities' protection), whereas only one systemic norm forming illiberal democracy (min- 
orities' protection) was fulfilled when the previous governments (Donald Tusk and Ewa Kopacz's governments) operated. Thus, it can be stated that the transition from liberal to illiberal democracy took place in the period of the functioning of Szydło's government. 